Selecting the Party Leader 
Series Editor: John Benyon, Director, Centre for the Study of Public Order, University of Leicester

A series which provides authoritative yet concise introductory accounts of key topics in contemporary political studies.

Other titles in the series:

Elections and Voting Behaviour in Britain

DAVID DENVER, University of Lancaster

Pressure Groups, Politics and Democracy in Britain WYN GRANT, University of Warwick

UK Political Parties since 1945

Edited by ANTHONY SELDON, Institute of Contemporary British

History

Politics and Policy Making in Northern Ireland

MICHAEL CONNOLLY, University of Ulster

Local Government and Politics in Britain

JOHN KINGDOM, Sheffield Polytechnic

British Political Ideologies

ROBERT LEACH, Leeds Polytechnic

British Government: The Central Executive Territory

PETER MADGWICK, Professor Emeritus, Oxford Polytechnic 


\section{Selecting the Party Leader: \\ Britain in Comparative}

Perspective

\section{R. M. PUNNETT}

University of Strathclyde

\section{言原 HARVESTER \\ 害焦 WHEATSHEAF}

New York London Toronto Sydney Tokyo Singapore 
First published 1992 by

Harvester Wheatsheaf

Campus 400, Maylands Avenue

Hemel Hempstead

Hertfordshire, HP2 7EZ

A division of

Simon \& Schuster International Group

ISBN 978-0-333-73910-5

ISBN 978-1-349-14899-8 (eBook)

DOI 10.1007/978-1-349-14899-8

C R. M. Punnett, 1992

All rights reserved. No part of this publication may be reproduced, stored in a retrieval system, or transmitted, in any form, or by any means, electronic, mechanical, photocopying, recording or otherwise, without the prior permission, in writing, from the publisher.

Disc conversion in 10/12 Times

by Columns Design and Production Services Ltd, Reading

British Library Cataloguing in Publication Data

A catalogue record for this book is available from the British Library

ISBN 978-0-7450-1227-8

ISBN 978-0-7450-1228-5

1234559695949392 
To Alison Sarah 


\section{Contents}

List of Figure and Tables

Preface

xii

1 Introduction

The party leader

Alternatives to election

An ideal system?

Types of system

Which method?

Notes

2 The 'Emergence' of the Party Leader:

The Conservatives until 1963

Customary processes 29

The emergence of Baldwin and Macmillan 34

The emergence of Lord Home $\quad 38$

The system condemned 44

Notes 49

3 The Election of the Party Leader by MPs

I: The Conservatives since 1965

The rules of election 53

Theory and practice $\quad 59$

vii 
The leader rejected

A very Tory coup

The system assessed

Notes

4 The Election of the Party Leader by MPs II: Labour until 1980

The case for election by MPs $\quad 82$

The PLP ballot $\quad 85$

The election of Michael Foot $\quad 89$

The system under attack 95

The emergence of the electoral college $\quad 99$

Notes 103

5 The Election of the Party Leader by Activists: Labour's Electoral College

The electoral college rules

The rules in operation

The 1992 contests

The electoral college assessed

The future of the electoral college 122

Notes

6 The Election of the Leader by Party Members: Liberals, Social Democrats and Liberal

Democrats

The Liberals

The Social Democrats

The Liberal Democrats

The limitations of direct democracy

Notes

7 Conclusion

A participatory revolution? 
CONTENTS

Making a difference

163

Remaining as leader

169

Notes

175

Index 


\section{Figure and Tables}

Figure 1.1 Leader-selection methods.

Table 2.1 Conservative party leaders 1881-1991.

Table 3.1 Conservative party leadership elections: votes per candidate.

Table 3.2 Conservative party leadership elections: candidates and ballots.

Table 4.2 Labour party leadership elections: candidates and ballots.

Table 4.3 1980 Labour party leadership election.

Table 4.4 Labour party special conference, January 1981: votes cast for alternative proposals for the electoral college structure. 
Table 5.1 Labour party leader and deputy leader elections 1981, 1983, 1988 and 1992.

Table 5.2 Impact of 1988 and 1983 leadership contests on Labour's opinion poll ratings.

Table 6.1 Liberal party leaders 1868-1988.

Table 7.1 Chronology of party leadership contests 1945-90. 


\section{Preface}

This is a study of the 'what, why and so what' of the process of selecting the party leader in Britain and elsewhere. It seeks to answer the questions: by what means does a party select its leader; why does it use that particular method; what consequences flow from its use of that method? The concern is not with political leaders in the plural, in the sense of the recruitment of elites, but with the selection of the individual who fills the post of leader of the party. While the prime focus of the book is the selection of the leader in the main British parties, the British experience is placed in a comparative context and is used to illustrate general features of leader-selection processes in competitive party systems. In particular, four basic methods of selection are identified and the British parties are used to illustrate those four methods.

My interest in party leaders has its roots in earlier studies of the Leader of the Opposition in Britain and the Prime Minister in Canada. The immediate stimulus for the book, however, was the realization, when called upon to prepare a short series of lectures on leader-selection procedures, that remarkably little had been written about the topic. A study of Labour's electoral college, and participation in a workshop on the selection of the party leader in western parties, organized for the European Consortium for Political Research (ECPR) by Tom Mackie in 1989, coincided with the preparation of this manuscript. Many of the themes that are covered in the book, in particular the analysis of the different types of selection systems in Chapter 1 , were discussed at the ECPR workshop. I am grateful to the participants in the workshop for the stimulus provided by our discussions. I am also 
grateful to Jennifer Punnett for her services as a research assistant and to Jack Vanderoef, John Sanderson and Gabriella Ilonszki for their comments on chapters.

I wish to thank the Carnegie Foundation, the Government of Canada and Ball State University, Indiana, for providing me with research grants. Among the many people who have helped with the physical preparation of the manuscript, I am especially grateful to Grace Hunter, Alison Bennett, Margaret Leckie and Florene Ball for preparing early drafts and to Maxine Riley, Terry Kingrea and Kim Hedge for processing the final draft with exceptional efficiency.

In retrospect it is probably not wise to dedicate books to your children: you have either to stop having children or persist in writing books. With the dedication of this book, however, the task is complete. 